NOTE: This is an author's version of an article published in Small Axe 43, vol. 18, no. 1 (2014): 7-21. http://smallaxe.dukejournals.org/content/18/1_43/7

\title{
Borderlands and Border Crossers: Migrants and Boundaries in the Greater Caribbean, 1840-1940
}

\section{Lara Putnam}

Borderlands are wider than borders, and people make them so. In cases where two states have successfully extended de facto control until bumping up against each other, and where the populace on each side displays a uniformity of language, culture, ancestry, and allegiance, we speak of borders, not borderlands. Such cases have not been typical of the Greater Caribbean, to put it mildly. Here, relocation and remixing have been the rule rather than the exception, and newcomers have more often sought to duck central state authority than impose it. People have moved to where states could not follow; states have stalemated each other, creating space for people to move. The same seacoasts that give maps of the Caribbean the illusion of clarity have aided the creation of messy borderlands galore - some at the swampy fringes far from the centers of power, others in port alleyways where loyalty, color, and culture refused to align as authorities expected. Borderlands index the disjuncture between states' territorial claims and their effective reach. For that reason, popular initiative and mobility are at the center of their stories. ${ }^{1}$

\footnotetext{
${ }^{1}$ This core appreciation is shared by approaches to borderlands as diverse as Gloria E. Anzaldúa, Borderlands/La frontera: The New Mestiza (San Francisco: Spinsters/Aunt Lute, 1987); Donna Guy and Thomas Sheridan, eds., Contested Ground: Comparative Frontiers on the Northern and Southern Edges of the Spanish Empire (Tucson: University of Arizona Press, 1998); and Charles V. Carnegie,
} 
This essay seeks to trace the changing configuration of Greater Caribbean borderlands over the momentous century that followed Spanish American continental independence and the end of slavery in the anglophone and francophone Caribbean. Necessarily this requires tracing as well the movements of the border crossers who made and remade borderlands through their travels, connections, and social creations. I will sketch what I see as the key emphases within the recent historiography of circumCaribbean borderlands, on the one hand, and Caribbean migrations, on the other, suggesting that despite a wealth of scholarly contributions the knowledge gained has been radically limited. We ask certain questions only about certain people in certain placesand for other people in other places, we ask no questions at all. As a result, significant swathes of experience are invisible within the cumulative historiography of Caribbean borderlands and border crossers.

Our optic, I will suggest, has been distorted by attention to those cases and places where centralized investment of foreign capital generated centralized migratory streams: conditions that favored perceptions of racial and cultural distance and discouraged the building or acknowledgment of connections between newcomers and nationals. One might think, to judge by the case studies available, that by the early twentieth century messy borderlands were largely a thing of the past. One might also think that subjugation to powerful employers and marginalization from surrounding societies were typical of the early-twentieth-century experience of Caribbeans abroad. Finally, one might think that the story of pre-World War II Caribbean labor migration was consistently a story of men.

Postnationalism Prefigured: Caribbean Borderlands (New Brunswick, NJ: Rutgers University Press, 2002). See also Charles V. Carnegie, "Reaching for the Border," Small Axe, no. 19 (February 2006): v-ix. 
In each case, one would be wrong. The narrowness of scholarly attention has distorted the breadth of Caribbean historical experience.

I will frame my discussion of the scholarship around topics rather than debates, because on the crucial issue of midrange and long-term outcomes-for sending societies, for receiving societies, and for migrants and their descendants — we have not given ourselves enough grounds for debate. This is mainly because of the patterns in case study selection described above. In the terminology of social scientific research design, we have selected our sample based on key independent variables - employer control and sociocultural separation — and the constrained array of case studies we have produced fails to reflect the full range of variation in dependent variables, that is, individual and collective outcomes.

But case selection has not been our only problem. Historians' primary research has tended to be single-sited and time-limited and shaped by an understandable sympathy for the perspective of our subjects. Thus the basic story we have told about Caribbean border crossers has been one of struggle against oppression, hard-won community solidarity, and partial and painful incorporation into surrounding societies.

This is an instance, I would suggest, where scholars' political sympathies regarding the past are a poor fit for the real needs of the present. As I write in September 2013, the Dominican Republic's Constitutional Court has just confirmed a law stripping citizenship from locally born children of nonpermanent immigrants, including seasonal workers, retroactive to 1929: scores of thousands of Dominicans of Haitian ancestry will become stateless as a result. Raids and deportations are being deployed against undocumented Guyanese in Barbados, amid accusations of profiling and harassment of 
the Guyanese community as a whole. Bahamian newspapers debate ways to withhold citizenship from children born locally to Haitian parents - roughly one-seventh of all children born in the Bahamas - even as Haitians form a mainstay of the service and construction labor force there. ${ }^{2}$

Do not let the litany confuse you. These outcomes are not universal. Nor are the border systems that create them. Other policies can be chosen, if enough voters and legislators believe that the benefits of incorporation outweigh the costs to society of systematic illegalization (or the cost to employers of losing access to rightless workers). Even the US visa and citizenship regime became, for a few months in 2013, a topic of open debate, its costly dysfunction momentarily exposed to discussion rather than masked by yelping about taller walls at the border.

If we want to argue to lawmakers across the hemisphere that reforming current policies on entry, employment, and citizenship could have positive impact, we would be well served to be able to report that the past offers something other than a uniform panorama of marginalization and suffering. And indeed, the Caribbean past does. Observing human mobility around the Greater Caribbean across multiple generations, we see significant variation across time and space in migrants' degree of autonomy, integration, and advance. Permanent otherness and impoverishment have been the exception rather than the rule. A fuller picture of the past can and should serve as a call to action in the present.

\section{Caribbean Borderlands and the Transition to Free Labor and Mobile Capital}

\footnotetext{
${ }^{2}$ William J. Fielding et al., "The Stigma of Being 'Haitian' in The Bahamas," College of the Bahamas Research Journal 14 (2008): 44, researchjournal.cob.edu.bs.
} 
Across the seventeenth and eighteenth centuries, imperial competition in the Greater Caribbean made it possible for people who sought not to be ruled-indigenous groups, escaped slaves, and motley others - to use strategic alliances and targeted violence to keep wide territories outside the control of any imperial state. The Central American coastal lands known as Mosquitia, the inland stretches of the Guianas in northeast South America, and the peninsula of Florida in southeast North America were the largest of these regions, but the same pattern created heterogeneous peoples in the interstices of empire all around the region.

Geopolitical realignment at the end of the eighteenth century shrank the British footprint in the Western Caribbean and the French footprint in the Eastern Caribbean. From Louisiana to Bluefields to St. Lucia, this left multilingual populations with few ties to the state claiming treaty rights over them. Meanwhile, several generations would pass before the nascent continental republics could begin to contend for effective control of the zones of refuge created in the colonial era.

As the nineteenth century progressed, Caribbean borderlands would be remapped in a process driven by two distinct phenomena: the halting but inexorable dismantling of slavery around the region, and a fundamental shift in the relationship between investment and empire. As had been the case in earlier eras, population movements would still follow the labor demand generated by investment. But now those movements would take the form of free or contract migration rather than forced enslavement and transport, and capital would routinely be invested outside of the investors' governing state. Profits could be reaped beyond the borders of formal empire. 
Both labor and capital were mobile in new ways, though the kinds of risks they faced were incommensurate. The uneven persistence of slavery (through 1834-38 in the British Caribbean, 1848 in the French and Danish Caribbean, 1854 in Venezuela, 1863 in the Dutch territories and the United States, 1873 in Puerto Rico, and 1886 in Cuba) made the threat of re-enslavement one constraint on people of color attempting to exercise their new freedom internationally. ${ }^{3}$ Meanwhile, certain trips were only feasible if someone else covered the cost of travel, which meant advance contracts demanding precommitment of labor (for seven years in the case of most South and East Asians traveling under contract of indenture; for shorter periods for British Caribbeans recruited for railroad or canal projects). Such arrangements radically limited negotiating power after arrival. Yet overall, as investors sought new profits from borderland terrains that had been sparsely exploited in the previous era, most of the labor was provided by border-crossing migrants who traveled on their own account.

The weight of sugar production shifted southeast (to Trinidad and Guiana) and northwest (to the Spanish-speaking Greater Antilles, now linked to US capital and markets). The bulk of coffee production moved from the Greater Antilles to the circumCaribbean highlands (Central America, Venezuela, Colombia), demanding seasonal workers from adjacent mestizo and indigenous population clusters. Then banana

\footnotetext{
${ }^{3}$ Jorge Chinea, Race and Labor in the Hispanic Caribbean: The West Indian Immigrant Worker Experience in Puerto Rico, 1800-1850 (Gainesville: University Press of Florida, 2005); Michael Toussaint, "Post-abolition Trinidad-Venezuela Relations: The Experience of Manumisos and Aprendizajes," Arts Journal 3, nos. 1-2: (March 2007): 184-201; Rebecca Scott and Jean Hébrard, Freedom Papers: An Atlantic Odyssey in the Age of Emancipation (Cambridge: Harvard University Press, 2012); Matthew J. Smith, "From the Port of Princes to the City of Kings: Jamaica and the Roots of the Haitian Diaspora," in Regine O. Jackson, ed., Geographies of the Haitian Diaspora (New York: Routledge, 2011), 17-33; Jorge Giovannetti, "Migración en las Antillas: Episodios de transterritorialidad, 1804-1945," in José A. Piqueras, ed., Historia comparada de las Antillas (Madrid: CSIC, forthcoming).
} 
cultivation for export was pioneered in the rainforested western rimlands, from 1899 on its transport largely monopolized by a handful of multinational exporters.

The rise of the US-run banana companies and their highly visible spread have overshadowed the fact that in the same decades saw many other sources of economic dynamism in the old borderlands, ones that did not share the horizontal and vertical integration that quickly became the hallmark of the banana industry. These prompted significant own-account population movement both across and within borders. There was gold (drawing Windward Islanders to Venezuela and British Guiana and spurring internal migration in Nicaragua and Honduras), cacao (drawing thousands of Grenadians and other small islanders to Trinidad and Venezuela and sustaining Jamaica-born migrants along Costa Rica's Talamanca coast), and various species of natural rubber (harvested by workforces that combined indigenes, afro-mestizos, and immigrant Afro-Caribbeans in borderland regions between British Honduras and Guatemala, Costa Rica and Panama, Colombia and Brazil, and Venezuela and British Guiana).

Ports at the unstable edges of empire, especially New Orleans, Port of Spain, and Santiago de Cuba, had long formed something like focalized borderlands within the Caribbean's social geography. Unlike the peripheral borderlands, the ports were so valuable they were never left formally unruled. Yet as in classic borderlands, port residents were mobile, polyglot, suspected of divided loyalty-distinctly unreliable vectors of any one state's rule. As border-crossing investment accelerated across the late nineteenth century and the early twentieth, the numbers of such places expanded. New shipping routes brought new sites into range for Caribbean sojourners. Places such as Tampico and Tampa became nodes of new migratory circuits. Most portentously, US 
northeastern seaboard cities such as Boston, Philadelphia, and New York were fused into trans-Caribbean shipping networks.

This development was most important for women. Across the postemancipation generations, both internal and inter-territorial migration to ports and capitals always included significant numbers of women, and often more women than men. Caribbean immigrant women ran boarding houses and sold meals in rimland ports with recently arrived migrant labor forces or worked as domestics in middle-class homes in more established metropoles like Caracas, Havana, and Port of Spain. By 1920, Manhattan would outpace all other destinations for Caribbean women seeking opportunity in foreign.

\section{The Distribution of Scholarship on Postemancipation Border Crossing}

I have traced this multigenerational story in some detail in order to underline how partial our scholarly research on borderlands and border crossers has been. We know a great deal about some of the above developments, and very little about others. There are reasons for this. Powerful employers generated the kind of migration that we easily see and track. It mattered to employers, it mattered to states, and (increasingly, as jobs became scarce in the 1920s) it mattered to local opponents.

Centrally organized labor recruitment created spatially concentrated settlements highly visible within receiving societies' human geography. This was all the more so given the active preference of employers like United Fruit and the Isthmian Canal Commission for creating divided workforces, both by where they recruited and by how 
they organized and treated workers on arrival. ${ }^{4}$ Recruited workers were separated from surrounding societies by perceived race, language, and cultural markers. As a result they were visible as outsiders in both the primary sources generated then and the secondary sources generated since. These secondary sources proliferated in the case of US-owned enterprises in particular: first in the form of boosterish reporting published for US readerships at the dawn of the twentieth century, then in the 1930s and again in the 1970s in nationalist denunciations published within the receiving societies.

In contrast, the kinds of migrations that kept borderlands borderlands, or created new ones, are much harder to track. Where population flows were decentralized and dispersed, where sojourners labored on their own account or for a large number of small entrepreneurs, where occupational segregation was not centrally planned and consistent but improvised and shifting, and where the languages, cultural knowledge, and perceived race of newcomers and locals overlapped, in all such instances, which is to say, in much of the Greater Caribbean, the story is much harder to recreate. Indeed, it may be hard to see that any significant border crossing went on at all.

The result is that we have a sizeable literature on the migrations linked to bananas and sugar and very little on those linked to cacao, rubber, or domestic service. We have more monographs about Caribbean life in early-twentieth-century Limón, Costa Rica, than we do about Caribbean life in early-twentieth-century Harlem, or Brooklyn, or Spanish Harlem. ${ }^{5}$ To illuminate our relative ignorance, let me use (imperfect) national

\footnotetext{
${ }^{4}$ Philippe Bourgois, Ethnicity at Work: Divided Labor on a Central American Banana Plantation (Baltimore, MD: Johns Hopkins University Press, 1989); Julie Greene, The Canal Builders: Making America's Empire at the Panama Canal (New York: Penguin, 2009); Jason M. Colby, The Business of Empire: United Fruit, Race, and US Expansion in Central America (Ithaca, NY: Cornell University Press, 2011).

${ }^{5}$ See, on Costa Rica within the last two decades alone, Trevor Purcell, Banana Fallout: Class, Color, and Culture among West Indians in Costa Rica (Los Angeles: Center for Afro-American Studies, University of
} 
census data to map out the locations of the largest Caribbean-born populations residing outside of their islands of origin, circa 1930.

California, Los Angeles, 1993); Aviva Chomsky, West Indian Workers and the United Fruit Company in Costa Rica, 1870-1940 (Baton Rouge: Louisiana State University Press, 1996); Ronny José Viales Hurtado, Después del enclave: Un estudio de la región atlántica costarricense (San José: Editorial Universidad de Costa Rica, 1998); Ronald Harpelle, The West Indians of Costa Rica: Race, Class, and the Integration of an Ethnic Minority (Montreal: McGill-Queen's University Press, 2001); Lara Putnam, The Company They Kept: Migrants and the Politics of Gender in Caribbean Costa Rica, 1870-1960 (Chapel Hill: University of North Carolina Press, 2002); Diana Senior Angulo, "La incorporación social en Costa Rica de la población afrocostarricense durante el siglo XX, 1927-1963" (MA thesis, Universidad de Costa Rica, 2007); Asia Leeds, "Representations of Race, Entanglements of Power: Whiteness, Garveyism, and Redemptive Geographies in Costa Rica, 1921-1950" (PhD diss., University of California, Berkeley, 2010). On other banana zones, see Douglas W. Kraft, "Making West Indians Unwelcome: Bananas, Race and the Immigrant Question in Izabal, Guatemala, 1900-1929" (PhD diss., University of Miami, 2006); Frederick Douglass Opie, Black Labor Migration in Caribbean Guatemala, 1882-1923 (Gainesville: University Press of Florida, 2009); Glenn Chambers, Race, Nation, and West Indian Immigration to Honduras (Baton Rouge: Louisiana State University Press, 2010). Meanwhile we have only one (albeit wonderful) modern social history of interwar British West Indian New York: Irma Watkins-Owens, Blood Relations: Caribbean Immigrants and the Harlem Community, 1900-1930 (Bloomington: Indiana University Press, 1996). Winston James, Holding aloft the Banner of Ethiopia: Caribbean Radicalism in Early TwentiethCentury America (New York: Verso, 1998), though focused in its bulk on key radical leaders, provides invaluable information, as do Yevette Richards, Maida Springer: Pan-Africanist and International Labor Leader (Pittsburgh: University of Pittsburgh Press, 2000) and Joyce Moore Turner with W. Burghardt Turner, Caribbean Crusaders and the Harlem Renaissance (Urbana: University of Illinois Press, 2005). On Boston in the same era, see Violet Showers Johnson, The Other Black Bostonians: West Indians in Boston, 1900-1950 (Bloomington: Indiana University Press, 2006). 


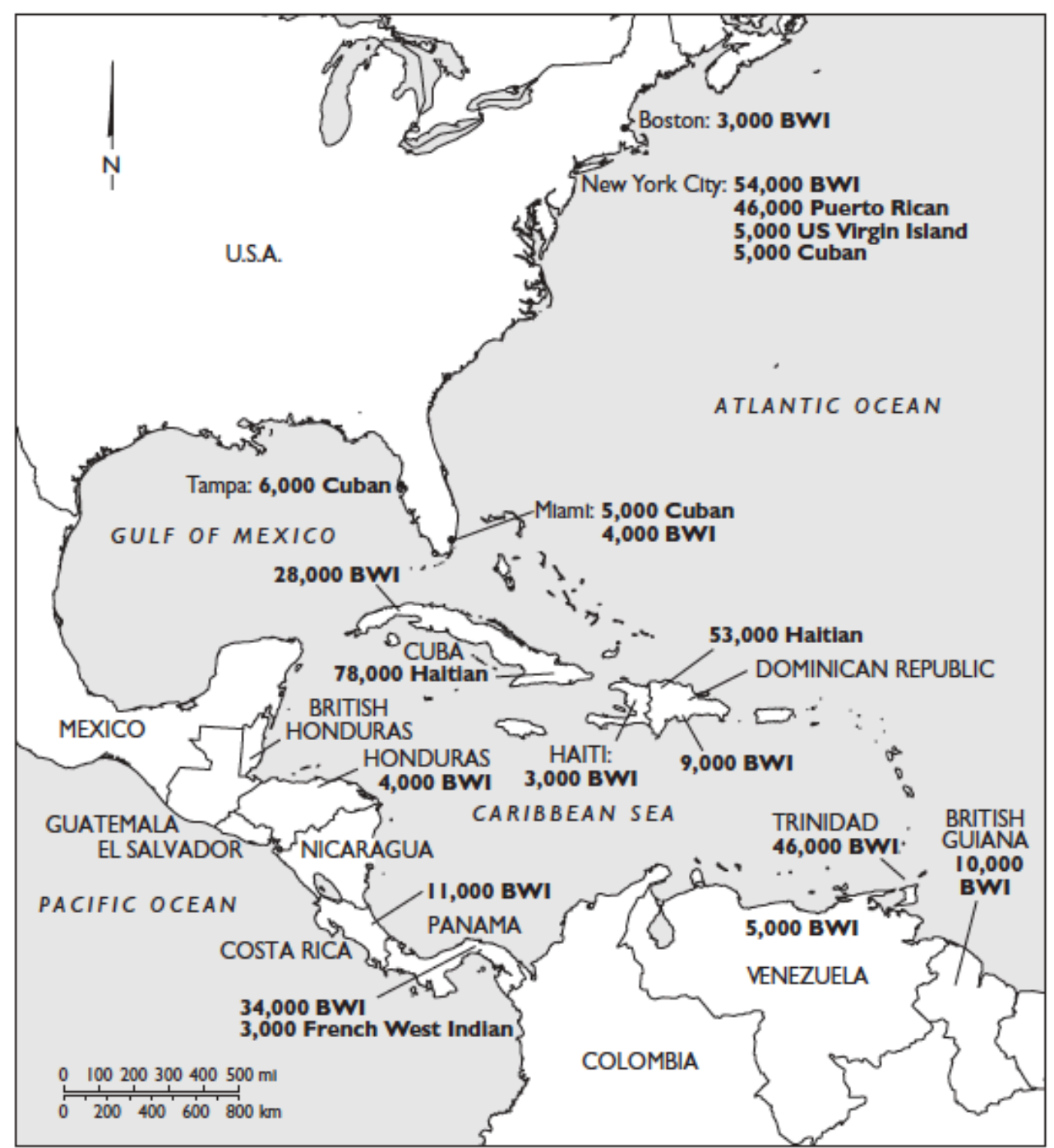

MAP: Caribbean Populations Born Elsewhere, circa 1930. Drawn by Bill Nelson; data and design by Lara Putnam.

Who were they, and where were they? Most numerous by far were the seventyeight thousand Haitians in Cuba (almost certainly an undercount). Another fifty-three thousand Haitians were tallied in the Dominican Republic. A similar fifty-four thousand British West Indians resided in New York City alone, alongside forty-six thousand Puerto Ricans in that same metropolis. Some eighteen thousand more "West Indians," almost all 
from British islands but including a smattering of Haitians and French and Dutch

colonials, resided elsewhere in the United States. Meanwhile, fully forty-six thousand

British West Indian migrants (Barbadians, Grenadians, Vincentians, St. Lucians) lived in

Trinidad. British West Indians in the Republic of Panama totaled twenty-three thousand,

with another eleven thousand in the adjacent Canal Zone; British West Indians tallied in

Cuba numbered twenty-eight thousand. The eleven thousand British West Indies-born

residents of Costa Rica just outnumbered the ten thousand British West Indian island-

born residents of British Guiana, who in turn just outnumbered the nine thousand British

West Indians in the Dominican Republic. Cubans in the United States numbered over

eighteen thousand overall, roughly six thousand of them in Tampa, five thousand in

Miami, and five thousand in New York City. ${ }^{6}$

The disproportion between the very large numbers of Haitians in Cuba and the

Dominican Republic and the very scarce scholarship on them in that era is immediately

clear, as is the disproportion between the indisputable centrality of New York to both

anglophone and Hispanic Caribbean migratory circuits by the end of the 1920s and the

\footnotetext{
${ }^{6}$ R. R. Kuczynski, Demographic Survey of the British Colonial Empire, vol. 3, West Indian and American Territories (London: Oxford University Press, 1953), 79-80, 156, 198-99, 341; Cuba, Comité estatal de estadísticas, Memorias inéditas del censo de 1931 (Havana: Editorial de Ciencias Sociales, 1978), 74; Cuba, Dirección general del censo, Censo de 1943 (Havana: P. Fernández, 1945), 888-89; República Dominicana, Dirección general de estadística nacional, Sección del censo, Población de la República Dominicana distribuida por nacionalidades: Cifras del censo nacional de 1935 (Ciudad Trujillo: Sección de Publicaciones de la Dirección General de Estadística, 1937), 5; US Bureau of the Census, Fifteenth Census of the United States, 1930, vol. 2, Population (Washington DC: Government Printing Office, 1933), 157, 231, 232, 250; US Bureau of the Census, Fifteenth Census of the United States, 1930, Outlying Territories and Possessions (Washington DC: Government Printing Office, 1932), 334-35; Venezuela, Ministerio de fomento, Dirección de estadística, Sexto censo de población, 1936, vol. 3 (Caracas: Tipografía Garrido, 1940), 5540-41; Colombia, Contraloría general de la República, Dirección del censo, Memoria y cuadros del censo de 1928 (Bogotá: Editorial Librería Nueva, 1930); República de Panamá, Secretaría de agricultura y obras públicas, Dirección general del censo, 1930 censo demográfico, vol. 1 (Panama: Imprenta Nacional, 1931), 21-23; Costa Rica, Base de datos del censo de 1927, ccp.ucr.ac.cr/censos/; República de Nicaragua, Censo general de 1920 (Managua: Tipografía nacional, n.d.), 4; Honduras, Dirección general de estadística, Resumen del censo general de población, levantado el 29 de junio de 1930 (Tegucigalpa: Tipografía Nacional, 1932), 32; Guatemala, Ministerio de fomento, Dirección general de estadística, Censo de la población de la república, 1921 (Guatemala: Talleres Gutenberg, 1924), 1:139, 2:57.
} 
relative scarcity of historical research on it. But of course, early-twentieth-century

Caribbean migration to New York had all the characteristics that I have argued made

borderlands border crossing hard to track. It was decentralized, own-account, scattered

across dispersed employers, and involved potentially blurry boundaries on all sides:

between English-speaking black people arriving from Barbados and English-speaking

black people arriving from North Carolina; between children of Jamaicans arriving from

Cuba and children of Cubans arriving from Cuba; between US Virgin Islanders and

Puerto Ricans who shared both colonial status and US citizenship; and more. How this all

played out in practice — which divides hardened and which dissolved — we frankly do not

know because the research has not yet been done. ${ }^{7}$

Note, too, that these statistics register only individuals born elsewhere, so they do not capture either the locally born second generation (whose inclusion, for instance, would bring the size of the British West Indian communities up to one hundred thousand for New York and around sixty thousand for Cuba and Panama alike). Moreover this 1930 snapshot gives no trace of the preceding history of borderlands absorption. We do not see here the children of Jamaicans who traveled to Panama in the 1880 s to work on the French Canal effort, the children of Cubans who traveled to Tampa in the 1880s to

\footnotetext{
${ }^{7}$ I am grateful to Francisco Scarano for pushing me on this point. Recent scholarship asks just this kind of question with regard to post-World War II Hispanic Caribbean migration, and in some cases includes at least a chapter shedding light on this earlier period. See Nancy Raquel Mirabal, "No Country, but the One We Must Fight For': The Emergence of an 'Antillean' Nation and Community in New York City, 18601901," in Agustín Laó-Montes and Arlene Dávila, eds., Mambo Montage: The Latinization of New York (New York: Columbia University Press, 2001); Jesse Hoffnung-Garskoff, A Tale of Two Cities: Santo Domingo and New York After 1950 (Princeton, NJ: Princeton University Press, 2008); Jorge Duany, Blurred Borders: Transnational Migration between the Hispanic Caribbean and the United States (Chapel Hill: University of North Carolina Press, 2011). See also Virginia Sánchez Korrol, From Colonia to Community: The History of Puerto Ricans in New York City, 2nd ed. (Berkeley: University of California Press, 1994); Susan D. Greenbaum, More than Black: Afro-Cubans in Tampa (Gainesville: University Press of Florida, 2002).
} 
roll cigars in Ybor City, the children of Grenadian and Vincentian men who traveled to northeast Venezuela in the 1880s to cultivate cacao for export to France.

The map also does not register other population movements that were fundamentally interrelated. A crucial one, of course, was migration from British India, which had carried over four hundred thirty thousand men and women into the Caribbean between the 1840s and 1916. As late as 1930, some forty thousand people who had made that journey themselves were still alive in British Guiana, and thirty-seven thousand in Trinidad; the second, third, and fourth generations around them, of course, were far more numerous. To what extent "time-expired" East Indians or their children joined other Caribbean working people in traveling into the borderlands in the era under discussion remains an open question within the historiography, in part because they are even harder to distinguish within the available sources. Boundaries blurred, but exactly which boundaries varied from place to place. Indo-Caribbean culis became smoothly absorbed into the larger collective of negros jamaiquinos in Limón, but in the same years their cousins became a distinct community (called by Spanish speakers babús) in Panama. ${ }^{8}$ Movement of East Indians from Trinidad to Venezuela seems to have been sizable at times. ${ }^{9}$ What of migration northward? Caribbean East Indians had been born outside the "Asiatic barred zone" established by US law, and thus were technically eligible for entry to the United States - or perhaps not, depending on which consular agent you asked. ${ }^{10}$ How many traveled to New York in the decade before further entry of any and all British

\footnotetext{
${ }^{8}$ Lara Putnam, "Undone by Desire: Migration, Sex across Boundaries, and Collective Destinies in the Greater Caribbean, 1840-1940," in Dirk Hoerder and Donna Gabaccia, eds., Connecting Seas and Connected Ocean Rims: Indian, Atlantic, and Pacific Oceans and China Seas Migrations from the 1830s to the 1930s, Studies in Global Social History, vol. 8 (Leiden: Brill, 2011).

${ }^{9}$ Winthrop R. Wright, Café con leche: Race, Class, and National Image in Venezuela (Austin: University of Texas Press, 1990), 64, 92.

${ }^{10}$ US National Archive, RG 84 Consular Posts, Bridgetown, Barbados, vol. 201: Correspondence, American Consulate, Barbados, 1923; vol. 2: Letter from US Consul, Trinidad, 23 October 1923.
} 
Caribbeans was radically curtailed by the Johnson-Reed Act of $1924 ?^{11}$ These questions point to another kind of blurred boundary we need to know more about.

Another kind of population movement that crucially shaped Caribbean borderlands in the nineteenth and early twentieth centuries was that between neighboring states, which often shared an overlapping range of language and culture as a result of a common imperial past. (The large-scale postemancipation flow from the Windward Islands to Trinidad and British Guiana, reflected in the map above, might be thought of as an insular instance of this broader phenomenon.) In most cases, such "near neighbor" migrants far outnumbered all other arrivals, yet within each nation's historiography both the handful of white European immigrants and the armfuls of Afro-Caribbean immigrants have tended to receive more attention. "Near neighbors" were the nineteen thousand Colombian-born residents of Venezuela in 1930 and the fifteen thousand Venezuelanborn residents of Colombia; the nineteen thousand Salvadorans in Honduras, the five thousand Hondurans in Nicaragua, and the nine thousand Nicaraguans in Costa Rica; the five thousand Mexicans in Guatemala and the five hundred sixty-three thousand Mexicans in the US Southwest and West. ${ }^{12}$ In several cases (including British Honduras, Honduras, and Costa Rica), these near-neighbor arrivals became a major presence alongside British West Indian immigrants in the circum-Caribbean borderlands. ${ }^{13}$

\footnotetext{
${ }^{11}$ Lara Putnam, "Unspoken Exclusions: Race, Nation, and Empire in the Immigration Restrictions of the 1920s in North America and the Greater Caribbean," in Leon Fink, ed., Workers across the Americas: The Transnational Turn in Labor History (New York: Oxford University Press, 2011), 267-93.

${ }^{12}$ Lara Putnam, "Migrants, Nations, and Empires in Transition: Native Claims in the Greater Caribbean, 1850s-1930s," in Nicola Foote and Michael Goebel, eds., Immigration and National Identities in Latin America, 1850-1950 (Gainesville: University Press of Florida, forthcoming).

${ }^{13}$ The case of the shifting perceptions and consequences of movement between British Honduras and Yucatán is brilliantly explored by Elisabeth Cunin, Administrar los extranjeros: raza, mestizaje, nación: Migraciones afrobeliceñas en el Territorio de Quintana Roo, 1902-1940 (México: CIESAS, IRD, Karthala collections Esclavages, forthcoming 2014).
} 
Internal migrations were significant, too. In Colombia and across Central America, they brought ever-greater numbers of "national workers" into the rimland borderlands where exports boomed. Jamaicans and their children were leaving Limón, Costa Rica, for Cuba and New York just as Costa Ricans from Guanacaste and the Central Highlands were seeking work in the banana zone in record numbers. AfroFloridians were departing Florida by the thousands for New York, Detroit, and Chicago as Bahamian migration to Miami construction sites and truck farms reached a peak. Placing internal migrations in supranational, regionwide context is a pending task.

In sum, the fact that we know much more about certain kinds of migratory flows means we understand the borderlands less accurately overall. The hypervisibility of centralized, employer-driven transfers, and the relative invisibility of cases where people traveled on their own, dispersed, and mixed in, causes a retroactive erasure of messiness, alliance, and integration. ${ }^{14}$ The problem is not that individual works on United Fruit Company labor, say, ignore heterogeneity and complexity; most of them make great efforts to reveal them. Rather, the problem is that the borderlands of the greatest heterogeneity and complexity are rarely studied at all.

Equally distorting is the fact that when we overfocus on migration driven by large employers we miss seeing women everywhere. As noted above, women crossed borders in significant numbers: selling food, shelter, or comfort in boomtown ports such as

\footnotetext{
${ }^{14}$ The conference cycle organized by Annette Insanally through the Latin American-Caribbean Centre, University of the West Indies-Mona is an important partial exception. Seeking to be as inclusive as possible, both in migratory circuits covered and in voices invited, the conferences shed light on corners rarely explored. Annette Insanally, Mark Clifford, and Sean Sheriff, eds., Regional Footprints: The Travels and Travails of Early Caribbean Migrants (Kingston: Latin American-Caribbean Centre, University of the West Indies, 2006). Another pioneering effort that puts inter-peripheral border-crossing at the center is Shalini Puri, ed., Marginal Migrations: The Circulation of Cultures within the Caribbean (Warwick: Macmillan Caribbean, 2003). See also Jorge Giovannetti, "Migración en las Antillas," and "Caribbean Studies as Practice: Insights from Border-Crossing Histories and Research,” Small Axe, no. 41 (July 2013): $74-87$.
} 
Limón, Colón, and Santiago de Cuba; working as domestic servants in settled cities with sizable bourgeoisies. From 1920 to 1924 - the height of the British West Indian influx to New York-women outnumbered men within that flow. ${ }^{15}$ As the sugar boom waned in Cuba, Jamaican women's earnings outpaced men's. “There isn't a woman from your country who is not employed," a Jamaican journalist was told in Havana in 1928. "They are preferred as house servants to any others. And what these poor creatures earn they have to share with their menfolk."16 Work in the needle trades was frequent, too, especially but not only in New York. Claudia Jones's mother did piecework on arrival from Trinidad, as did Kenneth Clark's mother on arrival from Panama. ${ }^{17}$ Yet we have no systematic assessment of British Caribbean women's place in Gotham's interwar industries, much less that of Puerto Rican women, much less their overlaps and differences.

\section{A Rich but Partial Regional Portrait}

Make no mistake, scholars have been busy doing interesting things. (I focus here on works published since 2000, more or less.) ${ }^{18}$ Recent work on Caribbean border crossers has offered unprecedented attention to transnational cultural production and social movements. Recent work on Central American borderlands (the only rimlands receiving sustained scholarly attention) has offered new insights into the making and remaking of

\footnotetext{
${ }^{15}$ US Bureau of the Census, Population, 498.

${ }^{16}$ Herbert G. DeLisser, "Our Labour in Cuba: Notes on Conditions," Gleaner, 30 January 1928, 12.

${ }^{17}$ Peter Meyer Filardo, "Dear Comrade Foster: The Following Is the Autobiographical (Personal, Political, Medical) History That I Promised . . Comradely, Claudia Jones (December 6, 1955)," American Communist History 4, no. 1 (2005): 85-93; Lara Putnam, "Kenneth Bancroft Clark," in Henry Louis Gates, Jr. and Franklin W. Knight, eds., Dictionary of Caribbean and Afro-Latin American Biography (New York: Oxford University Press, forthcoming); Richards, Maida Springer, 35; Watkins-Owens, Blood Relations, 25 .

${ }^{18}$ Furthermore, while I attempt to include key recent publications from across the region, my coverage is far more complete for North American publishers, journals, and dissertations.
} 
collective identities. A few efforts have tried to use borderlands as a new paradigm for rethinking either the Caribbean as a whole or particular spaces within it. I will address each of these, in turn.

The millennium's "transnational turn" in history and American studies both encouraged and benefitted from an outpouring of interest in (re)connections across the African diaspora. Caribbeans on the move were a key vector of such reconnection in the early twentieth century, as recent scholarship has made abundantly clear. One vertex of this scholarship is comprised of new studies of Caribbean migrants as performers and authors, usually during their time in New York (although London and Paris make appearances as well). ${ }^{19}$ Another cluster has focused on Caribbean migrants' role as pioneers of black internationalisms, from Marcus Garvey's Universal Negro Improvement Association to the black socialists and communists who fused denunciations of racism, imperialism, and capitalism. ${ }^{20}$ Here, too, British West Indians in New York and London have received the most prominent attention, although other

\footnotetext{
${ }^{19}$ Heather Hathaway, Caribbean Waves: Relocating Claude McKay and Paule Marshall (Bloomington: Indiana University Press, 1999); Brent Hayes Edwards, The Practice of Diaspora: Literature, Translation, and the Rise of Black Internationalism (Cambridge: Harvard University Press, 2003); Louis J. Parascandola, ed., Look for Me All around You: Anglophone Caribbean Immigrants in the Harlem Renaissance (Detroit, MI: Wayne State University Press, 2005); Michelle Ann Stephens, Black Empire: The Masculine Global Imaginary of Caribbean Intellectuals in the United States, 1914-1962 (Durham, NC: Duke University Press, 2005); Louis Chude-Sokei, The Last "Darky": Bert Williams, Black-on-Black Minstrelsy, and the African Diaspora (Durham, NC: Duke University Press, 2006).

${ }^{20}$ James, Holding Aloft; Ula Yvette Taylor, The Veiled Garvey: The Life and Times of Amy Jacques Garvey (Chapel Hill: University of North Carolina Press, 2002); Jason Parker, “'Capital of the Caribbean': The African American-West Indian 'Harlem Nexus' and the Transnational Drive for Black Freedom, 19401948," Journal of African American History 89, no. 2 (2004): 98-117; Susan Pennybacker, From Scottsboro to Munich: Race and Political Culture in 1930s Britain (Princeton, NJ: Princeton University Press, 2009); Eric D. Duke, "The Diasporic Dimensions of Caribbean Federation in the Early Twentieth Century," New West Indian Guide 83, nos. 3-4 (2009): 219-48; Erik S. McDuffie, Sojourning for Freedom: Black Women, American Communism, and the Making of Black Left Feminism (Durham, NC: Duke University Press, 2011); Minkah Makalani, In the Cause of Freedom: Radical Black Internationalism from Harlem to London, 1917-1939 (Chapel Hill: University of North Carolina Press, 2011).
} 
studies have begun to paint the contours of transnational political engagement among sojourners in Cuba and Central America. ${ }^{21}$

Our knowledge remains hampered by our collective tendency to ask certain kinds of questions for certain places only. We have fascinating studies of Afro-Caribbean migrants' religious practices on the islands and in the rimlands but not in the United States. ${ }^{22}$ We have careful studies of Caribbean migrants' labor experience in Central America and Cuba and nothing comparable for New York. ${ }^{23}$ And, as noted above,

\footnotetext{
${ }^{21}$ Jorge Giovannetti and Reinaldo Roman, eds., special issue of Caribbean Studies, "Garveyism in the Hispanic Caribbean," 31, no. 1 (2003): 1-259; Anne Macpherson, "Colonial Matriarchs: Garveyism, Maternalism, and Belize's Black Cross Nurses, 1920-1952," Gender and History 15, no. 3 (2003): 507-27; Carla Burnett, “'Are We Slaves or Free Men?': Labor, Race, Garveyism and the 1920 Panama Canal Strike," (PhD diss., University of Illinois at Chicago, 2004); Jorge L. Giovannetti, "The Elusive Organization of 'Identity': Race, Religion, and Empire Among Caribbean Migrants in Cuba," Small Axe, no. 19 (March 2006): 1-27; Daniel Dalrymple, "In the Shadow of Garvey: Garveyites in New York City and the British Caribbean, 1925-1950" (PhD diss., Michigan State University, 2008); Michael O. West, William G. Martin, and Fanon Che Wilkins, eds., From Toussaint to Tupac: The Black International since the Age of Revolution (Chapel Hill: University of North Carolina Press, 2009); Leeds, "Representations of Race"; Kaysha Corinealdi, "Redefining Home: West Indian Panamanians and Transnational Politics of Race, Citizenship, and Diaspora, 1928-1970" (PhD diss., Yale University, 2011); Adam Ewing, "Broadcast on the Winds: Diasporic Politics in the Age of Garvey, 1919-1940" (PhD diss., Harvard University, 2011); Frances Peace Sullivan, "Radical Solidarities: US Capitalism, Community Building, and Popular Internationalism in Cuba's Eastern Sugar Zone, 1919-1939” (PhD diss., New York University, 2012); Lara Putnam, Radical Moves: Caribbean Migrants and the Politics of Race in the Jazz Age (Chapel Hill: University of North Carolina Press, 2013). The latest addition to Robert Hill's magisterial series should inspire even more work along these lines; see Robert A. Hill, ed., The Marcus Garvey and Universal Negro Improvement Association Papers, vol. 11, The Caribbean Diaspora (Berkeley: University of California Press, 2012).

${ }^{22}$ Chomsky, West Indian Workers; Harpelle, West Indians of Costa Rica; Hélène Lee, The First Rasta: Leonard Howell and the Rise of Rastafarianism, trans. Lily Davis (Chicago: Lawrence Hill Books/Chicago Review Press, 2003); Matthew Casey, "Haitian Migrants in Cuba, 1902-1940" (PhD diss., University of Pittsburgh, 2012). For one attempt to rectify, see Putnam, Radical Moves, chap. 2. In regard to post-World War II migrations, of course, the topic is extensively treated.

${ }^{23}$ On Central America, see, in addition to sources in notes 4 and 5, Steve Marquardt, "'Green Havoc': Panama Disease, Environmental Change, and Labor Process in the Central American Banana Industry," American Historical Review 106, no. 1 (Feb. 2001): 49-80; John Soluri, Banana Cultures: Agriculture, Consumption, and Environmental Change in Honduras and the United States (Austin: University of Texas Press, 2005). On Cuba, see Marc McLeod, "Undesirable Aliens: Haitian and British West Indian Immigrant Workers in Cuba, 1898-1940" (PhD diss., University of Texas at Austin, 2000); Jorge L. Giovannetti, "Black British Subjects in Cuba: Race, Ethnicity, Nation, and Identity in the Migratory Experience, 18981938" (PhD diss., University of North London, 2001); Cadence Wynter, "Jamaican Labor Migration to Cuba, 1885-1930, in the Caribbean Context" (PhD diss., University of Illinois at Chicago, 2001); Audrey K. Charlton, "'Cat Born in Oven is not Bread': Jamaican and Barbadian Immigrants in Cuba between 1900 and 1959" (PhD diss., Columbia University, 2005); Jana K. Lipman, Guantánamo: A Working-Class History between Empire and Revolution (Berkeley: University of California Press, 2008); Casey, "Haitian Migrants in Cuba"; and, with more focus on the politics of labor than the experience of labor, Robert
} 
regarding some of the most enduring migratory circuits (that linking the Windwards,

Trinidad, Venezuela, and the Guianas, say, or Haiti and Eastern Cuba, or Haiti and the

Dominican Republic), for this early national period we have very few studies at all.

In the same decades, scholarship on rimland borderlands followed an equally

generative but entirely separate path. As civil wars in Central America ground to a

bloody halt in the mid 1990s, academics embraced the urgent task of excavating the

historical roots of the societal divides that had made genocidal violence possible.

Drawing intellectual tools from the international academic focus on the social

construction of ethnicity, nationality, and race, historians and anthropologists combined

painstaking archival research with oral history to track shifting collective identities across

tumultuous centuries. ${ }^{24}$ Several of these deep "histories of the present" focused on the

Caribbean rimlands in particular, as did other, more chronologically limited studies. ${ }^{25}$

Whitney and Graciela Chailloux Laffita, Subjects or Citizens: British Caribbean Workers in Cuba, 1900 1960 (Gainesville: University Press of Florida, 2013). Meanwhile on the Dominican Republic in this regard see Samuel Martínez, "From Hidden Hand to Heavy Hand: Sugar, the State, and Migrant Labor in Haiti and the Dominican Republic," Latin American Research Review 34, no. 1 (1999): 57-84. For one fascinating labor history of Hispanic Caribbeans in the United States that includes this era, see Adrian Burgos, Playing America's Game: Baseball, Latinos, and the Color Line (Berkeley: University of California Press, 2007).

${ }^{24}$ Jeffrey Gould, To Die in This Way: Nicaraguan Indians and the Myth of Mestizaje, 1880-1965 (Durham, NC: Duke University Press, 1998); Greg Grandin, The Blood of Guatemala: A History of Race and Nation (Durham, NC: Duke University Press, 2000); Virginia Q. Tilley, Seeing Indians: a Study of Race, Nation, and Power in El Salvador (Albuquerque: University of New Mexico Press, 2005); Justin Wolfe, The Everyday Nation-State: Community and Ethnicity in Nineteenth-Century Nicaragua (Lincoln: University of Nebraska Press, 2007); Charles R. Hale, Mas Que Un Indio: Racial Ambivalence and the Paradox of Neoliberal Multiculturalism in Guatemala (Santa Fe, NM: School of American Research Press, 2006) and the monumental compilation edited by Darío Euraque, Jeffrey Gould, and Charles R. Hale, Memorias del mestizaje: Cultura politica en Centroamérica de 1920 al presente (Guatemala: CIRMA, 2004).

${ }^{25}$ Charles R. Hale, Resistance and Contradiction: Miskitu Indians and the Nicaraguan State, 1894-1987 (Stanford, CA: Stanford University Press, 1996); Edmund T. Gordon, Disparate Diasporas: Identity and Politics in an African-Nicaraguan Community (Austin: University of Texas Press, 1998); Baron Pineda, Shipwrecked Identities: Navigating Race on Nicaragua's Mosquito Coast (New Brunswick, NJ: Rutgers University Press, 2006). See also Marc Edelman, "A Central American Genocide: Rubber, Slavery, Nationalism, and the Destruction of the Guatusos-Malekus," Comparative Studies in Society and History 40, no. 2 (April 1998): 356-90; Darío A. Euraque, "The Banana Enclave, Nationalism, and Mestizaje in Honduras, 1910s-1930s," in Aviva Chomsky and Aldo Lauria-Santiago, eds., Identity and Struggle at the Margins of the Nation-State: The Laboring Peoples of Central America and the Hispanic Caribbean (Durham, NC: Duke University Press, 1998); Alejandra Boza Villarreal, "Indígenas, comerciantes, 
Most recently, as international legal instruments aimed at protecting indigenous land rights carry increasing weight in Central America, the question of which self-identified Afro-descended groups can also claim indigenous status has acquired urgency and consequences. Scholars have tracked how this new valence on the borderlands past has shifted collective identities in the borderlands present. ${ }^{26}$

Despite the yeoman efforts of certain conference organizers, this literature on the long-term complexities of collective identity in Central America has remained largely separate from the scholarship on Caribbean migration to and through Central America. ${ }^{27}$ With its multitude of cases studies combining theoretical sophistication and longue durée empirical reconstructions, the Central Americanist literature offers invaluable insights into both the plasticity of identification and the durability of hierarchies, in each case shaped by politics local, regional, national, and international alike. This scholarship deserves to be more widely read by Caribbeanists, who will find parallels from Trinidad to Harlem, in addition to the more obvious resonance with Belize, Guyana, and Surinam. Despite the disconnect described above, it is clear that thinking about borderlands — both about their historical reality and about the term's analytic utility — is

\footnotetext{
transnacionales y estados: Población, comercio, y política entre las poblaciones indígenas de la Gran Talamanca, Costa Rica (1840-1930) (Chirripó, Estrella, Talamanca, y Pacífico Sur)" (MA thesis, Universidad de Costa Rica, 2004); Karl H. Offen, "The Geographical Imagination, Resource Economies, and Nicaraguan Incorporation of the Mosquitia, 1838-1909," in Territories, Commodities, and Knowledges: Latin American Environmental Histories in the Nineteenth and Twentieth Centuries, ed. Christian Brannstrom (London: Institute for the Study of the Americas, 2004).

${ }^{26}$ Juliet Hooker, "Indigenous Inclusion/Black Exclusion: Race, Ethnicity, and Multicultural Citizenship in Latin America," Journal of Latin American Studies 37, no. 2 (2005): 1-26; Jennifer Allan Goett, "Diasporic Identities, Autochthonous Rights: Race, Gender, and the Cultural Politics of Creole Land Rights in Nicaragua" (PhD diss., University of Texas, Austin, 2006); Keri Brondo, "Roots, Rights, and Belonging: Garifuna Indigeneity and Land Rights on Honduras's North Coast" (PhD diss., Michigan State University, 2006); Elizabeth Molnar, “"El problema de carácter existencial': Afro-Honduran Land Struggles (c. 19602010)" (MA thesis, University of Pittsburgh, 2011).

${ }^{27}$ Lowell Gudmundson and Justin Wolfe, eds., Blacks and Blackness in Central America: Between Race and Place (Durham, NC: Duke University Press, 2010).
} 
something Caribbean scholars are eager to do. ${ }^{28}$ This makes sense. Borderlands, as noted above, reflect the social and cultural consequences of the gaps between state claims and popular motion. Caribbean history can be read as a long-term counterpoint between human beings demanding mobility and powerful institutions attempting to limit it, in the form of chattel slavery in the eighteenth century, indenture in the nineteenth, or visabased border-control in the twentieth. Understanding how that counterpoint has remade hierarchies and collectives within Caribbean societies as well as between and beyond them is a crucial task.

New research trends offer promise. In a region of messy frontiers, none has been more painfully entangled than the Haitian-Dominican borderlands, site of an infamous massacre in 1937 and innumerable intimate connections before and since. ${ }^{29}$ Particularly welcome, then, is a new initiative by young scholars, deeply engaged with migrants' rights activism on the island, to pioneer a collective rethinking of "transnational Hispaniola." ${ }^{30}$ In a different mode, small stories from the edges turn out to have much to teach. Dogged researchers have offered unexpectedly illuminating windows onto the small-scale interactions that shaped borderland nooks ranging from the anglophone

\footnotetext{
${ }^{28}$ See, for example, Charles V. Carnegie and Samuel Martinez, eds., "Crossing Borders of Language and Culture," special issue of Small Axe, no. 19 (2006): 1-229.

${ }^{29}$ Lauren Derby, "Haitians, Magic, and Money: Raza and Society in the Haitian-Dominican Borderlands, 1900 to 1937," Comparative Studies in Society and History 36, no. 3 (1994): 488-526; Richard Lee Turits, "A World Destroyed, a Nation Imposed: The 1937 Haitian Massacre in the Dominican Republic," Hispanic American Historical Review 82, no. 3 (2002): 589-635; Samuel Martínez, "Not a Cockfight: Rethinking Haitian-Dominican Relations," Latin American Perspectives 30, no. 3 (May 2003): 80-101.

${ }^{30}$ April Mayes, Yolanda Martín, Carlos Decena, Kiran Jayaram, and Yveline Alexis, "Transnational Hispaniola: Towards New Paradigms in Haitian and Dominican Studies," Radical History Review, no. 115 (Winter 2013): 26-32. Mayes's own forthcoming monograph, The Mulatto Republic: Class, Race, and Dominican National Identity (Gainesville: University Press of Florida, forthcoming), offers a nuanced account of the roles of multiple insiders and outsiders in reshaping Dominican belonging. Invaluable recent attempts to grapple with the depth and breadth of the Haitian diaspora include Jackson, Geographies of the Haitian Diaspora; and Philippe Zacaïr, Haiti and the Haitian Diaspora in the Wider Caribbean (Gainesville: University Press of Florida, 2010).
} 
Colombian island of San Andrés to the Cayman archipelago to the neighborhoods of New Orleans. $^{31}$

I hope that we can take these initiatives and interests as stepping stones to a widened agenda for Caribbean history as a whole. Perceptions of the importance of certain labor forms and certain capital flows have dictated a geography of collective attention that leaves too many places in the dark. Our mosaic of Caribbean history in the century after emancipation, I suggest, is disproportionately full of accounts of centrally organized movement across clear cultural boundaries. Our attention to the importance of labor is unduly tied to cases where migrants labored for high-profile foreign employers. A more accurate portrait of who we were before we became who we are today will require greater attention to the Caribbean's blended frontiers and the work that went on within them. These include spaces of encounter between patwa-, patois-, and Spanishspeaking Caribbeans in eastern Venezuela, eastern Panama, and East Harlem alike.

A final element I hope new work on borderlands history will illuminate is the widely varying gender balance of different Caribbean migratory circuits, and the ways this shaped sending and receiving communities. Relatedly, we should be asking about the impact of specific border-control regimes on Caribbean family practice. ${ }^{32}$ In each case,

\footnotetext{
${ }^{31}$ Martha Hodes, "The Mercurial Nature and Abiding Power of Race: A Transnational Family Story," American Historical Review 108, no. 1 (2003): 84-118; Sharika Crawford, "A Transnational World Fractured but Not Forgotten: British West Indian Migration to the Colombian Islands of San Andrés and Providencia," New West Indian Guide 85, nos. 1-2 (2011): 31-52; Scott and Hébrard, Freedom Papers.

${ }^{32}$ Pioneering contributions that give prominent attention to the interplay of kinship and migration include Karen Fog Olwig, Cultural Adaptation and Resistance on St. John: Three Centuries of Afro-Caribbean Life (Gainesville: University Press of Florida, 1986); Constance Sutton and Elsa M. Chaney, eds., Caribbean Life in New York City: Sociocultural Dimensions (New York: Center for Migration Studies of New York, 1987, 1992); Mary Chamberlain, "Gender and the Narratives of Migration," History Workshop Journal, no. 43 (Spring 1997): 87-108; Chamberlain, Family Love in the Diaspora: Migration and the AngloCaribbean Experience (New Brunswick, NJ: Transaction Publishers, 2006). More recently, Deborah A. Boehm, Intimate Migrations: Gender, Family, and Illegality among Transnational Mexicans (New York: New York University Press, 2012); Lara Putnam, "The Ties Allowed to Bind: Kinship Legalities and
} 
this requires moving beyond the (accurate) insistence that women traveled and women mattered, to ask how many women traveled, how often they moved on, how this impacted intercommunal contact and household formation, and how this shaped societies over time. Moreover, much more extensive research on women as workers, and the opportunities they have sought, will be needed if we are to better understand women in families and the obligations they have shouldered.

All of this would allow historians to speak with greater authority about issues that dominate debate over immigration policy today: assimilation, social spending, secondgeneration outcomes. Rather than throw up our hands at the inflammatory anecdotes that pass for informed debate from Arizona to Santo Domingo, we could use historical data to inform the debate. ${ }^{33}$

$* * *$

Port-au-Prince, Haiti; Colón, Panama; and the cane cutters' camps of Okeelanta, Florida, seem suitable poster children for the tragic cost of Caribbean history. The most salient features of these communities in the eyes of most outsiders are that they are very black and very, very poor. In these three cases — one longtime sending society, one long-ago receiving society, and one current migratory destination — we seem to see the results of Caribbean people's position as a vulnerable mobile labor force, exploited at the whim of international capital, marginalized from the more prosperous citizenries around them.

Migration Restriction in the Interwar Americas," International Labor and Working-Class History, no. 83 (August 2013): 191-209.

${ }^{33}$ See, for example, Douglas S. Massey, Jorge Durand, Nolan J. Malone, Beyond Smoke and Mirrors: Mexican Immigration in an Era of Economic Integration (New York: Russell Sage Foundation, 2003); Aviva Chomsky, "They Take Our Jobs!" and Twenty Other Myths about Immigration (Boston: Beacon, 2007). 
It's not that that story is not true. But it is a fragment we misread when we fail to see the whole. The immiseration of Haiti despite its long generations as exporter of migrants, the marginalization of immigrants' descendants in Colón, and the exploitation of the Jamaicans and others laboring today under the $\mathrm{H} 2$ visa program are atypical when viewed against the panorama of Caribbean borderlands and border crossers as a whole. Struggle and adversity have been universal, yes. But for them to end in impoverishment and isolation has been the exception rather than the rule.

Awareness of that broader pattern should be for students of the Caribbean past a call to arms. Port-au-Prince, Colón, and Okeelanta are deeply unnatural artifacts, created by policies and patterns that could have been different. ${ }^{34}$ Their entrenched poverty should inspire not cynicism or despair but anger. It didn't have to be that way. A fuller comparative understanding of the history of circum-Caribbean borderlands and border crossers can help us make the case for change.

\section{Acknowledgments}

I am grateful to Jorge Giovannetti and two Small Axe reviewers for insightful comments on a previous draft, and to Miguel Tinker-Salas for his encouragement regarding an even earlier version.

\footnotetext{
${ }^{34}$ A vital contribution making visible the history and harms of US guestworker policy is Cindy Hahamovitch, No Man's Land: Jamaican Guestworkers in America and the Global History of Deportable Labor (Princeton, NJ: Princeton University Press, 2011). Okeelanta is the setting of Stephanie Black's 1990 documentary H-2 Worker.
} 